\title{
The Influence of Capital Concentration on Brazilian Non-Financial Public Companies' Indebtedness Behavior
}

\author{
José Renato de Paula Souza Jardim¹, José Odálio dos Santos ${ }^{2}$, Peter Vaz da Fonseca1 \\ ${ }^{1}$ Mackenzie Presbyterian University, São Paulo, Brazil \\ ${ }^{2}$ Pontifical Catholic University of Sao Paulo, São Paulo, Brazil \\ Email: jrenatojardim@gmail.com, j.odalio@pucsp.br, peter@ebpocontabil.com.br
}

How to cite this paper: de Paula Souza Jardim, J. R., dos Santos, J. O., \& da Fonseca, P. V. (2022). The Influence of Capital Concentration on Brazilian Non-Financial Public Companies' Indebtedness Behavior. Theoretical Economics Letters, 12, 216-228. https://doi.org/10.4236/tel.2022.121012

Received: December 17, 2021

Accepted: February 12, 2022

Published: February 15, 2022

Copyright $\odot 2022$ by author(s) and Scientific Research Publishing Inc. This work is licensed under the Creative Commons Attribution International License (CC BY 4.0).

http://creativecommons.org/licenses/by/4.0/

\begin{abstract}
One of the main financial policies is related to the capital structure to be defined by the companies. For this reason, studies related to factors determining the capital structure have a high priority on the research agenda in finance area. This being so, the proposal is to investigate whether the nature of the company's shareholding control-family, foreign, state-owned-affects its capital structure. It is the first work that uses real shareholding control. For the development of this research, the publicly traded Brazilian companies listed in B3 are adopted as a sample. The analyzed sample covers 128 Brazilian companies listed in B3, between 2010 and 2017, excluding companies from the financial sector. It is necessary to study each company report to discover last-and true-shareholding control (Reference Forms). To verify the influence of the capital structure, regression models with panel data are used (fixed effect and robustness). The results are consistent with the expected ones: 1) the excessive concentration of family capital impairs indebtedness, which, due to the control loss aversion, reduces the financing by debt; 2) the concentration of foreign capital favors companies' indebtedness, as they have more efficient management, better access to financing sources and better investment opportunities, and, 3) the concentration of state capital favors indebtedness, since these companies are of government's interest to maximize the country's development, and have low capital costs arising from development banks.
\end{abstract}

\section{Keywords}

Corporate Governance, Ownership Structure and Capital Concentration

\section{Introduction}

The influence of the ownership structure on companies' performance has its ini- 
tial milestone with the publication of the book The Modern Corporation and Private Property, by Berle \& Mean, 1932. The core objective of this work was to present the shareholding pulverization of large American companies and the divergences of interests between managers and shareholders. The authors observed that the pulverization, empirically studied, would increase the managers' power, since they could make decisions benefiting themselves and disregarding the shareholders. From the ownership point of view, the capital structure is partially determined by the objectives of those who are in the company's control and, therefore, if the company has a concentrated structure, it tends to have fewer agency problems. In summary, the agency problem is around the minority controllers and shareholders (Jensen \& Meckling, 1976). According to La Porta et al. (2000), in countries where the owners' rights are weakly protected, the control of voting shares has enormous value, for it provides the controllers with the opportunity to expropriate the other agents.

Studies have been developed in the last decades, discussing the influence and the determinants of the ownership structure on the capital structure and the performance of companies (Fayez et al., 2019; Vitolla et al., 2020). According to the agency theory, the ownership structure facilitates managerial control, improving financial performance, but it may also lead to majority-minority conflicts within business organizations (Raimo et al., 2020). Noteworthy is that the relationship between capital structure and ownership structure still has ground to be explored, which is why it justifies efforts to expand research on the subject, especially in Brazil, where the capital market is in development and capital concentration is more likely to occur in family companies (Mardones \& Cuneo, 2020).

In this context, there is the guiding question of this research: what is the influence of the type of capital concentration-family, foreign capital and governmental-on the Brazilian public companies' indebtedness? Therefore, the objective of this research is to identify whether the Brazilian public companies' capital structure is influenced by the characteristic of the capital structure. To answer the research question, the general purpose of this research is: to analyze the ownership and control structures of publicly traded companies in Brazil, between 2010 and 2017, based on data compiled in company reports provided to CVM (Securities and Exchange Commission) called Reference Forms (RF), which have been used since their implementation. Deviations in voting rights among shareholders will be estimated, determining by category the largest controlling investor. After the identification of these major investors which will be categorized, statistical and econometric methods are used to verify their correlation with the companies' indebtedness.

\section{Theoretical Framework}

\subsection{Ownership Concentration and Capital Structure}

In general terms, Modigliani \& Miller (1958) described that the company cannot 
change the total value of its assets by changing the proportions of its capital structure, as the company's value will be the same, regardless of any capital structure chosen. What is relevant is the composition and nature of the company's assets. Subsequently, Modigliani \& Miller (1963), considering the existence of corporate taxes, concluded that the company should work close to one hundred percent, which would only make sense if companies did not go bankrupt. However, given the bankruptcy possibility that may affect companies, they should establish an optimal indebtedness level, in an intermediate position between zero and one hundred percent. The tradeoff theory, for Eckbo \& Kisser (2021), assumes that the optimal capital structure is reached when companies make a combination of equity with third party capital, aiming at maximizing the company's value based on the tax benefit. According to Vaz da Fonseca and Nascimento Jucá (2020) tax is a determinant for capital structure. The theory is also called as the counterbalance theory.

As mentioned above, the capital structure is partly determined by the objectives of those who are in the company's control. Evidence was found on the impact of the ownership concentration on their ownership management and ownership concentration (Gyapong et al., 2021). Hypothesized that the identity of large owners-family, bank, institutional investor, government and other companies) has important implications for the companies' performance. Studies show that the ownership structure may influence the quality of financial information and, thus, it plays an effective role in investors' decision making (Saona et al., 2020). The research showed that the family nature of companies in Europe has a significant impact on the leverage level, and this impact varies according to the legal framework and the institutional environment. The results of the study showed that family companies have less leverage, supporting the theory that family businesses are more averse to an increase in the debt level, due to the risk of insolvency and bankruptcy, as a result of having a poorly diversified portfolio.

\subsection{Ownership Structure and Type of Concentration}

The separation between ownership and control and the resulting problems among agents are at the center of discussions about corporate governance (Shliefer \& Vishny, 1997). According to La Porta et al. (2000), the ownership concentration varies among countries, and for developing countries, the ownership concentration would be an effective response to low legal protection, to low guarantee of law enforcement, and to the existence of weak institutions that would be unable to protect investors from possible expropriation by managers and controlling shareholders. For the authors, companies having a concentration of ownership of voting right shares equal to or greater than $10 \%$ already have concentrated capital. Zaid et al. (2020) present two main problems between ownership structure and agency: the first, when the ownership structure is pulverized, occurs between the main shareholders and managers, and the second, when concentrated, it happens between controlling and minority shareholders, when the mi- 
nority shareholders are the main ones and the controllers are the agents. The author mentions that structural changes in the economy, such as trade opening, currency stabilization and privatizations made a high volume of foreign investment entering the country, as a counterpart to the reduction of government participation in companies, but there was no change in the control dilution.

Regarding family companies, research shows that they tend to have simple management and strategies, a single cash for the company and the family, use of company's assets/goods for private purposes and preponderance of family interests in company's decisions, which influences the company's capital structure decisions family management tends to have an aversion of losing organization's control and inhibits the contracting of third party debts, as this decision requires the adoption of better governance standards, and the firm undergoes a careful evaluation by international credit agencies, investors and other creditors (Villalonga \& Amit, 2020).

For companies with foreign capital participation, according to researches by Cheng et al. (2020), there is a positioning of companies from an emerging country that can make use of international partners as a way to seek learning about the global business environment. According to the authors, companies attracting foreign investors, either directly through partnerships or indirectly through support and information to senior management, tend to be more aware of investment opportunities worldwide, favoring indebtedness.

Concerning the state-owned companies, the study developed by Jiang et al. (2021) found, among the results, that government-controlled companies can get lower debt costs, which may imply a greater tendency to go into debt. The authors state that some companies, due to political connections or national economic interests, have more access to funds from development banks and, also, companies that, being state-owned or from regulated sectors, also have greater discipline and greater access to funds in the domestic and international markets.

\section{Methodology}

\subsection{Database}

The sample analyzed covers all Brazilian companies listed on Brazilian Stock Exchange (B3), between 2010 and 2017, since the conceiving of the reference forms (FRE). The companies in the financial sector are excluded from the sample, as their peculiar features and leverage composition could distort the analysis. Financial companies have specific regulations and they also have differentiated capital structures in relation to the other sector. The concentration of capital has been manually obtained (FRE). Therefore, adjustments are made with the exclusion of missing data and of the variables considered as outliers. This information is extracted from the Capital IQ database.

Table 1 shows the composition evolution of the final sample, consisting of 128 non-financial companies. 
Table 1. Composition evolution of the final sample.

\begin{tabular}{cc}
\hline Description & Number of companies \\
\hline B3 (except those classified in the economic & 256 \\
sector as "financial and others") & 128 \\
$(-)$ companies with unavailable data & 128 \\
(=) final sample & \\
\hline
\end{tabular}

In order to achieve the best level of detail for the study of pyramidal ownership structures, the reference form is used, which shows in detail how the shareholders' participation in the corporate voting capital is structured and, from it, it is possible to break the pyramidal structures to obtain a greater level of detail. The reference form is the main account report of publicly-held companies, available in the CVM database, which communicates the companies' control structure, which is used in this work. CVM Instruction No. 480/09 in paragraphs 3 and 4 of its article 24, establishes certain events determining the obligation for issuers registered in Categories A and B to update, within 7 (seven) business days from the event date, the RF fields whose information is affected by them. Therefore, there may be different versions of these forms for the year of the fiscal exercise. For this research, the last active report of each year, generally spread in the following year, is used.

\subsection{Exploratory Variables and Equations of Econometric Models}

In this subsection, the exploratory variables used in the research were evidenced as a way to demonstrate the possible relationship of the dependent variable with the independent ones, as shown in Table 2.

Based on the study variables, highlighted in Table 2, and as a way of measuring the relationships between the dependent and independent variables, the general model was structured:

$$
D E B T_{i t}=\alpha+\beta_{1} O C T_{i, t}+\beta_{2} C V_{i, t}+u_{i, t}
$$

in which:

$i$ and $t$. represent the company and the year, respectively.

OCT: \% of elementary characteristics of the ownership structure-family, foreign, state, as shown in Table 2.

$D E B T$ : the debt indicator as shown in Table 2.

$C V$ : control variables as shown in Table 2 .

$u_{i, t}:$ error term

To verify whether the concentration degree and the family control influence the sample companies' debt structure, the criteria by La Porta et al. (2000) are used, which employ the $10 \%$ cut-off of the voting rights.

\subsection{Statistical Procedures}

The main quantitative analysis procedures applied were: 1) the Shapiro-Wilk 
Table 2. Study variables.

\begin{tabular}{|c|c|c|c|}
\hline Variables & Acronym & Measurement method & Source \\
\hline Family concentration & FAMDUM_10 & $\begin{array}{l}\text { Family dummy with } \\
10 \% \text { cut-off }\end{array}$ & CVM \\
\hline $\begin{array}{l}\text { Concentration of } \\
\text { foreign capital }\end{array}$ & FORDUM_10 & $\begin{array}{l}\text { Foreign dummy with } \\
10 \% \text { cut-off }\end{array}$ & CVM \\
\hline State concentration & GOVDUM_10 & $\begin{array}{l}\text { Government dummy } \\
\text { with } 10 \% \text { cut-off }\end{array}$ & \\
\hline Size & SIZE & LN (Assets) & $S \& P$ \\
\hline Volatility & VOL & (Standard deviation Ebit)/Assets & $S \& P$ \\
\hline Profitability (yield) & Yield & Ebit/Total Assets & $S \& P$ \\
\hline Profitability & PRO & Ebitda & $S \& P$ \\
\hline Growth Opportunity & GROW & $\frac{(\text { ROL1 }- \text { ROL0 })}{\text { ROL0 }}$ & $S \& P$ \\
\hline Tangibility & TANG & Fixed Assets/Total Assets & $S \& P$ \\
\hline Long-term debt & LTD & Debts over 1 year & S \& P \\
\hline Accounting debt & $\mathrm{ACD}$ & $\begin{array}{l}\text { Total Debts/Total Assets } \\
\text { (Accounting) }\end{array}$ & $S \& P$ \\
\hline Market debt & MKD & $\begin{array}{l}\text { Total Debts/Total Assets } \\
\text { (to market) }\end{array}$ & $S \& P$ \\
\hline $\begin{array}{c}\text { Long-term } \\
\text { debt/book value }\end{array}$ & BVD & Debts over 1 year/book value & $S \& P$ \\
\hline $\begin{array}{c}\text { Long-term } \\
\text { debt/market equity }\end{array}$ & MKED & $\begin{array}{c}\text { Debts over } 1 \\
\text { year/market equity }\end{array}$ & $S \& P$ \\
\hline Net debt/EBITDA & NDE & Net Debt/EBITDA & $S \& P$ \\
\hline Net debt/book value & NDBV & Net Debt/Book Value & $S \& P$ \\
\hline Net debt/market equity & NDMKE & Net Debt/Market Equity & S \& P \\
\hline
\end{tabular}

test, to assess whether the observations of publicly-held companies had a return distribution close to the normal distribution, and 2) the T-test, used to know whether the difference among the sample means is significant to conclude that there are differences or not for the compared data. To choose the most suitable model, the following tests are used: the Chow test, which signals, among the stacked data or fixed-effect models, which is the most adjusted; the Breusch Pagan test, to identify the most appropriate model, considering the stacked data or random-effect models, and the Hausman test, with the objective of verifying which of the effects, fixed or random, is the most suitable for the study model with the equation variables. For the purpose of confirmatory tests, multicollinearity tests were applied so that none of the independent or exploratory variables explain the same function as another. For this, the following statistical 
methods were applied: 3) analysis of absence of multicollinearity (VIF test - Variance Inflation Factor), considering the segregation value equal to 10 . In other words, the multicollinearity analysis is applied when, in the econometric model, there is the possibility that two or more explanatory variables of the model have a correlation with each other (Gujarati et al., 2012). For the purpose of correcting and adjusting heteroscedasticity, the command in the STATA robust software was applied, transforming the residues into homoscedastical, that is, enabling the distribution of residues as a constant variance.

\section{Results}

887 observations were used for the 128 publicly-held companies in the sample, presenting the average results for each of the variables, standard deviation, minimum and maximum of observations (Table 3 ).

In the descriptive statistics (Table 3 ), long term market value leverage (0.28) is lower than the book value (0.75). Under the Brazilian accounting law, improving fixed asset value according to the market price is not permitted, which may explain part of the difference shown above. Net debt to Ebitda has a mean of 2.64 and the total accounting debt $(0.87)$ is higher than the total market debt $(0.33)$.

Table 3. Descriptive statistics of the study variables of the econometric model.

\begin{tabular}{|c|c|c|c|c|c|}
\hline Variable & Obs & Average & Standard deviation & Min & $\operatorname{Max}$ \\
\hline \multicolumn{6}{|c|}{ Control variables \& independent } \\
\hline FAMILY & 896 & 0.42 & 0.32 & 0.00 & 1.00 \\
\hline FOREIGN & 896 & 0.09 & 0.15 & 0.00 & 1.00 \\
\hline GOVERNMENT & 896 & 0.06 & 0.13 & 0.00 & 1.00 \\
\hline SIZE & 896 & 3.14 & 0.82 & 0.43 & 5.53 \\
\hline YIELD & 852 & 0.07 & 0.07 & -0.10 & 0.38 \\
\hline GROW & 869 & 0.37 & 0.48 & 0.00 & 3.83 \\
\hline RISK & 896 & 0.06 & 0.06 & 0.01 & 0.35 \\
\hline TANG & 874 & 0.38 & 0.22 & 0.00 & 0.92 \\
\hline \multicolumn{6}{|c|}{ Indebtedness variables-dependent } \\
\hline LTD & 867 & 1.53 & 2.82 & 0.00 & 15.98 \\
\hline $\mathrm{ACD}$ & 847 & 0.34 & 0.18 & 0.00 & 0.97 \\
\hline MKD & 562 & 1.00 & 0.80 & 0.00 & 2.99 \\
\hline BVD & 773 & 0.75 & 0.96 & 0.00 & 6.83 \\
\hline MKED & 769 & 0.28 & 0.17 & 0.02 & 0.92 \\
\hline NDE & 609 & 2.64 & 1.67 & 0.00 & 6.93 \\
\hline NDBV & 692 & 0.87 & 0.92 & 0.00 & 5.20 \\
\hline NDMKE & 772 & 0.33 & 0.19 & 0.00 & 0.91 \\
\hline
\end{tabular}


After evidencing the descriptive statistics of the study variables, the analysis and discussion of the econometric models was carried out in relation to the theoretical framework. To this end, Tables 4-6 are prepared, which present the econometric model result for panel data with fixed effects (chosen after the application of the identification tests of the most appropriate model).

In Table 4, effects of family concentration, there is a negative $5 \%$ significance, as expected, for net debt to book value (NDBV). For net debt to Ebitda (NDE) and long-term debt to book value (BVD), there is a $10 \%$ negative significance. This type of concentration-family-appears to make the access to debt difficult, that is, the family is hostile to the control loss. When the proxy is measured by equity, this leverage indicator is observed as being impaired by the voting right concentration to family members. Family was found out as preferring to use cash flows to finance the operation. Regarding net debt to Ebitda, it is a measure widely used as a covenant and, because of this, there is a need for better management and influence of creditors in the company's decision-making.

Table 4. Effects of family concentration on capital structure.

\begin{tabular}{|c|c|c|c|c|c|c|c|c|}
\hline \multirow{2}{*}{ VARIABLES } & (1) & (2) & (3) & (4) & (5) & (6) & (7) & (8) \\
\hline & LTD & $\mathrm{ACD}$ & MKD & BVD & MKED & NDE & NDBV & NDMKE \\
\hline \multirow{2}{*}{ FAMDUM_10 } & -0.284 & -0.008 & -0.036 & $-0.184^{*}$ & -0.016 & $-0.259^{\star}$ & $-0.197^{\star \star}$ & -0.020 \\
\hline & $(-1.43)$ & $(-0.56)$ & $(-0.14)$ & $(-1.91)$ & $(-1.31)$ & $(-1.68)$ & $(-1.99)$ & $(-1.35)$ \\
\hline \multirow{2}{*}{ SIZE } & $1.822^{\star * *}$ & $0.038^{* * *}$ & $0.908^{\star \star \star *}$ & $0.179^{* * *}$ & $0.026^{* * *}$ & -0.037 & $0.108^{\star *}$ & -0.004 \\
\hline & $(9.45)$ & $(4.52)$ & $(5.91)$ & $(3.85)$ & $(3.16)$ & $(-0.44)$ & $(2.00)$ & $(-0.47)$ \\
\hline \multirow{2}{*}{ YIELD } & $-2.766^{\star *}$ & -0.147 & $-5.417^{\star * *}$ & 0.427 & -0.008 & $\mathrm{n} / \mathrm{a}$ & 0.877 & $-0.270^{\star *}$ \\
\hline & $(-2.27)$ & $(-1.09)$ & $(-7.49)$ & $(0.57)$ & $(-0.08)$ & $\mathrm{n} / \mathrm{a}$ & $(1.03)$ & $(-2.21)$ \\
\hline \multirow{2}{*}{ GROW } & $-0.342^{* *}$ & $-0.118^{\star * *}$ & $-0.376^{* * *}$ & $-0.338^{\star * \star}$ & $-0.18^{\star * *}$ & $-1.490^{* * *}$ & $-0.446^{* * *}$ & $-0.195^{\star * *}$ \\
\hline & $(-2.39)$ & $(-7.06)$ & $(-5.14)$ & $(-4.49)$ & $(-8.79)$ & $(-9.08)$ & $(-5.21)$ & $(-8.85)$ \\
\hline \multirow{2}{*}{ RISK } & -0.894 & -0.144 & $-28.691^{* * *}$ & -0.753 & $-0.41^{\star * *}$ & $-2.750^{\star *}$ & 0.677 & $-0.284^{\star *}$ \\
\hline & $(-0.67)$ & $(-1.23)$ & $(-3.48)$ & $(-0.99)$ & $(-3.24)$ & $(-2.35)$ & $(0.65)$ & $(-2.15)$ \\
\hline \multirow{2}{*}{ TANG } & $-0.636^{\star}$ & $-0.068^{\star *}$ & $-1.269^{* * *}$ & -0.093 & $-0.053^{\star}$ & 0.304 & 0.009 & 0.012 \\
\hline & $(-1.92)$ & $(-2.47)$ & $(-3.48)$ & $(-0.70)$ & $(-1.91)$ & $(1.10)$ & $(0.06)$ & $(0.42)$ \\
\hline EFFECT & FIXED & FIXED & FIXED & FIXED & FIXED & FIXED & FIXED & FIXED \\
\hline VIF & 1.24 & 1.24 & 1.24 & 1.24 & 1.21 & 1.03 & 1.21 & 1.19 \\
\hline OBSERVATIONS & 803 & 794 & 544 & 731 & 736 & 591 & 653 & 736 \\
\hline $\mathbf{R}^{2}$ ADJUSTED & 0.2570 & 0.1278 & 0.1768 & 0.0514 & 0.1965 & 0.1844 & 0.0579 & 0.2718 \\
\hline
\end{tabular}

Note: $n$ /a means not applicable. Significance Levels: ${ }^{\star *} 1 \% ;{ }^{*} 5 \%$ and ${ }^{\star} 10 \%$. The above regression considered indebtedness as dependent variable, and FAMDUM_10 (family with voting rights greater than 10\%), size, growth, profitability (yield), tangibility, sector, risk and profitability as explanatory variables in the period between 2010 and 2017. The assumption of homoscedasticity of the residues was evaluated by means of the White and Breusch-Pagan tests, indicating heteroscedasticity. The results obtained through the VIF test indicate that there is no significant correlation between the variables, since all the values presented are below 10. Thus, panel regression and fixed effect modeling must be used. Errors were robustly estimated for heteroscedasticity and autocorrelation of errors. 
Table 5. Effects of foreign capital on the capital structure.

\begin{tabular}{|c|c|c|c|c|c|c|c|c|}
\hline \multirow{2}{*}{ VARIABLES } & (1) & (2) & (3) & (4) & (5) & (6) & (7) & (8) \\
\hline & LTD & $\mathrm{ACD}$ & MKD & BVD & MKED & NDE & NDBV & NDMKE \\
\hline \multirow{2}{*}{ FORDUM_10 } & -0.043 & 0.000 & 0.061 & -0.056 & $0.027^{\star \star}$ & 0.194 & 0.000 & $0.033^{\star *}$ \\
\hline & $(-0.24)$ & $(0.03)$ & $(0.65)$ & $(-0.78)$ & $(2.24)$ & $(1.37)$ & $(0.01)$ & $(2.53)$ \\
\hline \multirow{2}{*}{ SIZE } & $1.828^{\star * *}$ & $0.038^{\star * \star}$ & $0.907^{\star * *}$ & $0.197^{\star * *}$ & $0.026^{* * *}$ & -0.031 & $0.121^{\star \star}$ & -0.004 \\
\hline & $(9.44)$ & $(4.68)$ & $(5.93)$ & (4.19) & (3.18) & $(-0.37)$ & $(2.22)$ & $(-0.49)$ \\
\hline \multirow{2}{*}{ YIELD } & $-2.695^{\star \star}$ & -0.147 & $-5.431^{\star * *}$ & 0.453 & 0.008 & $\mathrm{n} / \mathrm{a}$ & 0.896 & $-0.258^{\star *}$ \\
\hline & $(-2.19)$ & $(-1.09)$ & $(-7.51)$ & $(0.60)$ & $(0.08)$ & $\mathrm{n} / \mathrm{a}$ & $(1.06)$ & $(-2.08)$ \\
\hline \multirow{2}{*}{ GROW } & $-0.355^{\star *}$ & $-0.12^{\star * *}$ & $-0.372^{\star * *}$ & $-0.35^{* * *}$ & $-0.18^{\star * *}$ & $-1.51^{\star * *}$ & $-0.46^{\star * *}$ & $-0.19^{* * *}$ \\
\hline & $(-2.49)$ & $(-7.09)$ & $(-5.06)$ & $(-4.79)$ & $(-8.76)$ & $(-9.12)$ & $(-5.52)$ & $(-8.78)$ \\
\hline \multirow{2}{*}{ RISK } & -0.788 & -0.133 & $-28.96^{\star * *}$ & -0.502 & $-0.35^{\star * *}$ & $-2.077^{\star}$ & 1.018 & -0.212 \\
\hline & $(-0.59)$ & $(-1.16)$ & $(-3.51)$ & $(-0.70)$ & $(-2.72)$ & $(-1.78)$ & $(1.06)$ & $(-1.61)$ \\
\hline \multirow{2}{*}{ TANG } & $-0.688^{\star *}$ & $-0.069^{\star *}$ & $-1.268^{\star \star *}$ & -0.139 & -0.045 & 0.350 & -0.017 & 0.022 \\
\hline & $(-2.02)$ & $(-2.43)$ & $(-3.48)$ & $(-1.07)$ & $(-1.56)$ & $(1.24)$ & $(-0.12)$ & $(0.76)$ \\
\hline EFFECT & FIXED & FIXED & FIXED & FIXED & FIXED & FIXED & FIXED & FIXED \\
\hline VIF & 1.24 & 1.24 & 1.24 & 1.24 & 1.21 & 1.04 & 1.21 & 1.20 \\
\hline OBSERVATIONS & 803 & 794 & 544 & 731 & 736 & 591 & 653 & 736 \\
\hline $\mathrm{R}^{2}$ ADJUSTED & 0.2553 & 0.1274 & 0.1776 & 0.0458 & 0.2005 & 0.1831 & 0.0497 & 0.2762 \\
\hline
\end{tabular}

Notes: $\mathrm{n} / \mathrm{a}$ means not applicable. Significance Levels: ${ }^{* *} 1 \%$; ${ }^{\star *} 5 \%$ and ${ }^{\star} 10 \%$. The above regression considered indebtedness as dependent variable, and FORDUM_10 (foreign capital with voting rights greater than 10\%), size, growth, profitability (yield), tangibility, sector, risk and profitability as explanatory variables in the period between 2010 and 2017. The assumption of homoscedasticity of the residues was evaluated by means of the White and Breusch-Pagan tests, indicating heteroscedasticity. The results obtained through the VIF test indicate that there is no significant correlation between the variables, since all the values presented are below 10. Thus, panel regression and fixed effect modeling must be used. Errors were robustly estimated for heteroscedasticity and autocorrelation of errors.

Table 6. Effects of government on the capital structure.

\begin{tabular}{|c|c|c|c|c|c|c|c|c|}
\hline \multirow{2}{*}{ VARIABLES } & (1) & (2) & (3) & $(4)$ & (5) & (6) & (7) & (8) \\
\hline & LTD & $\mathrm{ACD}$ & MKD & BVD & MKED & NDE & NDBV & NDMKE \\
\hline \multirow{2}{*}{ GOVDUM_10 } & $1.017^{\star * *}$ & $0.029^{\star}$ & $0.620^{* * *}$ & 0.123 & $0.078^{* * *}$ & -0.023 & -0.083 & $0.041^{\star *}$ \\
\hline & $(3.66)$ & (1.95) & $(3.33)$ & $(1.37)$ & (5.98) & $(-0.14)$ & $(-0.93)$ & $(2.48)$ \\
\hline \multirow{2}{*}{ SIZE } & $1.734^{\star * *}$ & $0.035^{* * *}$ & $0.935^{* * *}$ & $0.181^{* * *}$ & $0.015^{\star}$ & -0.023 & $0.133^{\star *}$ & -0.009 \\
\hline & $(9.52)$ & $(4.06)$ & (6.19) & $(3.86)$ & $(1.82)$ & $(-0.27)$ & $(2.36)$ & $(-1.14)$ \\
\hline \multirow{2}{*}{ YIELD } & $-2.300^{\star}$ & -0.134 & $-5.394^{* * *}$ & 0.517 & 0.056 & $\mathrm{n} / \mathrm{a}$ & 0.853 & $-0.240^{\star}$ \\
\hline & $(-1.91)$ & $(-0.98)$ & $(-7.55)$ & $(0.70)$ & $(0.52)$ & $\mathrm{n} / \mathrm{a}$ & $(1.01)$ & $(-1.95)$ \\
\hline \multirow{2}{*}{ GROW } & $-0.312^{\star *}$ & $-0.117^{\star \star *}$ & $-0.381^{\star \star *}$ & $-0.344^{\star \star \star}$ & $-0.179^{\star * *}$ & $-1.506^{\star * *}$ & $-0.468^{\star * *}$ & $-0.195^{\star \star *}$ \\
\hline & $(-2.26)$ & $(-7.02)$ & $(-5.28)$ & $(-4.64)$ & $(-8.92)$ & $(-9.19)$ & $(-5.51)$ & $(-8.94)$ \\
\hline
\end{tabular}




\begin{tabular}{|c|c|c|c|c|c|c|c|c|}
\hline RISK & $\begin{array}{l}-1.286 \\
(-0.97)\end{array}$ & $\begin{array}{l}-0.168 \\
(-1.44)\end{array}$ & $\begin{array}{c}-23.526^{\star * *} \\
(-2.84)\end{array}$ & $\begin{array}{l}-0.668 \\
(-0.89)\end{array}$ & $\begin{array}{c}-0.481^{\star \star \star} \\
(-4.01)\end{array}$ & $\begin{array}{l}-2.277^{\star} \\
(-1.87)\end{array}$ & $\begin{array}{l}1.180 \\
(1.20)\end{array}$ & $\begin{array}{c}-0.308^{\star *} \\
(-2.33)\end{array}$ \\
\hline TANG & $\begin{array}{l}-0.569^{\star} \\
(-1.67)\end{array}$ & $\begin{array}{l}-0.067^{\star *} \\
(-2.42)\end{array}$ & $\begin{array}{c}-1.546^{\star \star \star} \\
(-4.19)\end{array}$ & $\begin{array}{l}-0.107 \\
(-0.80)\end{array}$ & $\begin{array}{l}-0.046^{\star} \\
(-1.68)\end{array}$ & $\begin{array}{l}0.268 \\
(0.95)\end{array}$ & $\begin{array}{l}-0.020 \\
(-0.14)\end{array}$ & $\begin{array}{l}0.012 \\
(0.41)\end{array}$ \\
\hline EFFECT & FIXED & FIXED & FIXED & FIXED & FIXED & FIXED & FIXED & FIXED \\
\hline VIF & 1.24 & 1.24 & 1.24 & 1.22 & 1.19 & 1.04 & 1.24 & 1.21 \\
\hline OBSERVATIONS & 803 & 794 & 544 & 731 & 736 & 591 & 653 & 736 \\
\hline $\mathrm{R}^{2}$ ADJUSTED & 0.2761 & 0.1313 & 0.1979 & 0.0477 & 0.2324 & 0.1803 & 0.0510 & 0.2770 \\
\hline
\end{tabular}

Note: $n$ /a means not applicable. Significance Levels: ${ }^{\star *} 1 \%$; ${ }^{\star *} 5 \%$ and ${ }^{\star} 10 \%$. The above regression considered indebtedness as dependent variable, and GOVDUM_10 (government with voting rights greater than 10\%), size, growth, profitability (yield), tangibility, sector, risk and profitability as explanatory variables in the period between 2010 and 2017. The assumption of homoscedasticity of the residues was evaluated by means of the White and Breusch-Pagan tests, indicating heteroscedasticity. The results obtained through the VIF test indicate that there is no significant correlation between the variables, since all the values presented are below 10. Thus, panel regression and fixed effect modeling must be used. Errors were robustly estimated for heteroscedasticity and autocorrelation of errors.

As for companies being able to attract foreign investors, they tend to have greater investment opportunities, have better governance and, consequently, get more indebtedness. The presence of foreign capital, in turn, may bring resources and learning to the company, favoring its investment process and, therefore, the need for financing. There is a positive relationship between foreign capital (FOREIGN) and indebtedness, and it is significant at $5 \%$ in variables (5) and (8) - table 5-, long-term debt to market equity (MKED) and net debt to market equity (NDMKE). Not least, the presence of foreign capital in the company's ownership tends to be a positive signal for other creditors and investors, when there is the need for financing.

Therefore, according to Table 6 , for companies with state participation, a positive and $1 \%$ significant relationship is observed in variables (1), (3), long-term debt (LTD) and market debt (MKD). As for net debt to market equity (NDMKE), there is a $5 \%$ significance, and for variable (2), accounting debt (ACD), a $10 \%$ significance. These results show that there is a indebtedness benefit for government controlled companies, as they are companies tending to have interests for the development of the country, have, in general, government support and low capital cost (access to BNDES). Furthermore, size (SIZE) has a beneficial relationship with indebtedness, in line with the trade-off theory; profitability (YIELD) shows a negative sign for indebtedness, as it would be aligned with the propensity to pecking order behavior, in which companies prioritize the use of cash flow to finance the investment; the risk variable is in accordance with the theory, since companies with more volatile results naturally tend to be less indebted, due to the greater probability of having financial distress, and for growth (GROW) and tangibility (TANG), the results were different from the ones expected in theories. 


\section{Final Considerations}

The objective of the present research was to identify whether the capital structure of Brazilian public companies is influenced by the concentration characteristic. For the development of the research, the publicly traded Brazilian companies listed in B3 were adopted as a sample. The research worked with data from 128 companies, in the period between 2010 and 2017. This research contributes, in the light of the theory of decisions on capital structure, the impact of ownership concentration on indebtedness. In addition, reference forms were used to obtain the highest level of information about shareholders and the type of ownership structure. Another contribution is the use of net debt, a widely used concept in the market, but little explored in scientific and academic works in Brazil.

Through the application of econometric models with panel data, there is the possibility to verify the existence of a negative relationship between the excessive concentration of family capital in net debt to book value, net debt to Ebitda and long-term debt to book value, according to what is expected, since family concentration tends to use equity, for they are averse to the loss of corporate control. For companies with access to foreign capital, the ratio is positive for indebtedness, with long-term debt to market equity and net debt to market equity the equations with statistical significance, corroborating that these companies tend to have greater investment opportunities and more efficient management. Furthermore, for companies with state concentration, there is statistical and positive significance for indebtedness, in the equations long-term debt, market debt, net debt to market equity and accounting debt, which corroborates with the expected, since companies with access to state resources tend to be of interest to the country's development and, therefore, they gain access to development banks and low interest costs. A limitation of this research is that it refers only to Brazil, as an example of developing country, not including any other country. For future studies, the following are recommended: 1) adoption of a database with privately held Brazilian companies; 2) a database with companies from other countries, for comparison purposes; and 3) testing variables of capital structure other than those addressed in this research.

\section{Conflicts of Interest}

The authors declare no conflicts of interest regarding the publication of this paper.

\section{References}

Berle, A. A., \& Means, G. C. (1932). The Modern Corporation and Private Property. Transaction Pub, 81, 782-785. https://doi.org/10.2307/3308267

Cheng, Z., Li, L., \& Liu, J. (2020). The Impact of Foreign Direct Investment on Urban PM2.5 Pollution in China. Journal of Environmental Management, 265, Article ID: 110532. https://doi.org/10.1016/j.jenvman.2020.110532

Eckbo, B. E., \& Kisser, M. (2021). Tradeoff Theory and Leverage Dynamics of High-Fre- 
quency Debt Issuers. Review of Finance, 25, 275-324.

https://doi.org/10.1093/rof/rfaa018

Fayez, M., Ragab, A., \& Moustafasoliman, M. (2019). The Impact of Ownership Structure on Capital Structure: An Empirical Study on the Most Active Firms in the Egyptian Stock Exchange. Open Access Library Journal, 6, 1-13.

https://doi.org/10.4236/oalib.1105266

Gujarati, D. N., Porter, D. C., \& Gunasekar, S. (2012). Basic Econometrics. Tata McGrawHill Education. https://doi.org/10.1007/s10490-019-09672-2

Gyapong, E., Ahmed, A., Ntim, C. G., \& Nadeem, M. (2021). Board Gender Diversity and Dividend Policy in Australian Listed Firms: The Effect of Ownership Concentration. Asia Pacific Journal of Management, 38, 603-643.

http://link.springer.com/10.1007/s10490-019-09672-2

Jensen, M. C., \& Meckling, W. H. (1976). Theory of the Firm: Managerial Behavior, Agency Costs and Ownership Structure. Journal of Financial Economics, 3, 305-360. https://doi.org/10.1016/0304-405X(76)90026-X

Jiang, X., Shen, J. H., Lee, C. C., \& Chen, C. (2021). Reforma estrutural do lado da oferta e ajuste dinâmico da estrutura de capital: Evidências de empresas chinesas listadas. Pacific-Basin Finance Journal, 65, Article ID: 101482.

http://www.sciencedirect.com/science/article/pii/S0927538X20306946

La Porta, R., Lopez-de-Silanes, F., Shleifer, A., \& Vishny, R. (2000). Proteção ao investidor e governança corporativa. Journal of Financial Economics, 58, 3-27. https://doi.org/10.1016/S0304-405X(00)00065-9

Mardones, J. G., \& Cuneo, G. R. (2020). Capital Structure and Performance in Latin American Companies. Economic Research-Ekonomska Istraživanja, 33, 2171-2188. https://doi.org/10.1080/1331677X.2019.1697720

Modigliani, F., \& Miller, M. H. (1958). O custo de capital, finanças corporativas e a teoria do investimento. American Economic Review, 48, 261-297. https://www.jstor.org/stable/1812919

Modigliani, F., \& Miller, M. H. (1963). Corporate Income Taxes and the Cost of Capital: A Correction. The American Economic Review, 53, 433-443. http://www.jstor.org/stable/1809167

Raimo, N., Vitolla, F., Marrone, A., \& Rubino, M. (2020). The Role of Ownership Structure in Integrated Reporting Policies. Business Strategy and the Environment, 29, 2238-2250. https://doi.org/10.1002/bse.2498

Saona, P., Muro, L., \& Alvarado, M. (2020). How Do the Ownership Structure and Board of Directors' Features Impact Earnings Management? The Spanish Case. Journal of International Financial Management \& Accounting, 31, 98-133. https://doi.org/10.1111/jifm.12114

Shleifer, A., \& Vishny, R. W. (1997). A Survey of Corporate Governance. The Journal of Finance, 52, 737-783. https://doi.org/10.1111/j.1540-6261.1997.tb04820.x

Vaz da Fonseca, P., \& Nascimento Juca, M. (2020). The Influence of Taxes on Foreign Direct Investment: Systematic Literature Review and Bibliometric Analysis. European Research Studies Journal, 23, 55-77. https://doi.org/10.35808/ersj/1580

Villalonga, B., \& Amit, R. (2020). Family Ownership. Oxford Review of Economic Policy, 36, 241-257. https://doi.org/10.1093/oxrep/graa007

Vitolla, F., Raimo, N., Rubino, M., \& Garzoni, A. (2020). The Determinants of Integrated Reporting Quality in Financial Institutions. Corporate Governance: The International Journal of Business in Society, 20, 429-444. https://doi.org/10.1108/CG-07-2019-0202 
Zaid, M. A., Abuhijleh, S. T., \& Pucheta-Martínez, M. C. (2020). Ownership Structure, Stakeholder Engagement, and Corporate Social Responsibility Policies: The Moderating Effect of Board Independence. Corporate Social Responsibility and Environmental Management, 27, 1344-1360. https://doi.org/10.1002/csr.1888 